\title{
Nye sepsiskriterier kan føre til forsinket behandling
}

\author{
De nye kliniske sepsiskriteriene kan føre til forsinket diagnostikk og nedprioritering av alvorlig syke pasienter.
}

Nye qSOFA- (Quick Sequential Organ Failure Assessment) kriterier er ment å erstatte de tidligere brukte SIRS- (systemisk inflammatorisk respons-syndrom) kriteriene (1). Mange akuttmedisinske pasientforløp starter utenfor sykehus, og definisjoner og rutiner som ikke tar hensyn til dette, kan potensielt virke mot sin hensikt. Vårt perspektiv er fra en interkommunal legevakt og øyeblikkelig hjelp-døgnenhet, 160 kilometer fra nærmeste sykehus.

\section{Sepsis}

Sepsis er en svært alvorlig tilstand med høy morbiditet og mortalitet (2). Den totale insidensen er ukjent, men man regner med at sepsis er en av de viktigste årsakene til alvorlig, akutt sykdom på verdensbasis (1). Sepsis bidrar til mellom en tredel og halvparten av dødsfall på sykehus (3). Sepsispasientene er i praksis en tidskritisk pasientgruppe, på samme måte som den mer etablerte internasjonale kvintetten akutt koronarsyndrom, hjertestans, hjerneslag, traumer og pustevansker.

Sepsis har inntil nylig vært definert som mistenkt infeksjon med samtidig tilstedeværelse av to eller flere SIRS-kriterier (1). Endringer i hjertefrekvens, kroppstemperatur, respirasjonsfrekvens og leukocytter er kroppens tegn på inflammasjon, og de indikerer ikke nødvendigvis en livstruende, dysregulert vertsrespons på infeksjon. Kriteriene er således verken sensitive eller spesifikke for sepsis, og derfor må man i praksis bruke mye klinisk skjønn når man stiller diagnosen sepsis tidlig i forløpet. Det er vist at tidlig deteksjon og rask oppstart av behandling med antibiotika og væske reduserer mortalitet og komplikasjonsrate (2).

\section{Fra SIRS til qSOFA}

I februar 2016 publiserte European Society of Intensive Care Medicine og Society of Critical Care Medicine en ny konsensus-

\section{RAMME 1}

qSOFA- (Quick Sequential Organ

Failure Assessment) kriterier:

Respirasjonsfrekvens $\geq 22 /$ min - 1 poeng

Endret mental status (GCS < 15) - 1 poeng

Systolisk blodtrykk $\leq 100 / \mathrm{mm} \mathrm{Hg}-1$ poeng

qSOFA-skår $\geq 2$ poeng økt fra baseline = mulig sepsis definisjon av sepsis og nye kliniske sepsiskriterier. Sepsis defineres nå som livstruende organdysfunksjon forårsaket av en dysregulert vertsrespons på infeksjon.

Basert på retrospektive journalopplysninger fra omtrent 149000 sykehuspasienter med mistenkt infeksjon identifiserte man hvilke

\section{«God akuttmedisinsk behandling krever helhetlige pasientforløp
med samkjørte behand-
lingsalgoritmer»}

tilgjengelige kliniske variabler som var sterkest assosiert med 30-dagers mortalitet og/eller opphold på intensivavdeling over tre dager. Disse variablene blir til sammen kalt SOFA-variabler.

SOFA-variablenes testegenskaper ble så testet retrospektivt på et stort datamateriale fra ulike amerikanske sykehus. Basert på dette ble mistenkt infeksjon og SOFA-skår $\geq 2$ foreslått som nye kliniske sepsiskriterier. For pasienter utenfor intensivavdeling har en enklere variant av SOFA, qSOFA (ramme 1), vist å ha omtrent tilsvarende prediktiv verdi. En økning av qSOFA-skår $\geq 2$ ved infeksjon øker mortaliteten betraktelig, og mistenkt infeksjon og qSOFA-skår $\geq 2$ foreslås som nye kriterier for å mistenke sepsis utenfor intensivavdelingene (1).

Forfatterne av den nye sepsisdefinisjonen understreker at fravær av økt qSOFA-skår ikke må føre til forsinket diagnostikk og behandling, og at SIRS-kriteriene fortsatt er viktige for å identifisere infeksjoner, men altså ikke for å vurdere om pasienten har sepsis (1).

Hvordan bruke den nye definisjonen? Hvordan man i praksis skal bruke den nye definisjonen på sepsis, tolkes ulikt i det akuttmedisinske fagmiljøet. Enkelte har vært tydelige på at qSOFA-kriteriene bør erstatte SIRS-kriteriene som screeningverktøy for sepsis (4). Andre mener at qSOFAkriteriene ikke skal brukes på denne måten, og peker på at kriteriene er laget og validert som et prognostisk verktøy, ikke et screeningverktøy (5). Det har også vært hevdet at det er for tidlig å ta i bruk de nye sepsiskriteriene fordi analysene av kriterienes egen- skaper kan være utsatt for bias, og fordi de ikke har vært testet prospektivt (6).

De nye sepsiskriteriene er kun validert for pasienter på sykehus, og det finnes få studier av kriterienes testegenskaper utenfor sykehus. Det er nylig gjort en retrospektiv evaluering av testegenskapene til qSOFA-skår $\geq 2$ for prehospital identifisering av pasienter med alvorlig sepsis eller septisk sjokk. Her ble det funnet at en prehospital qSOFA-skår $\geq 2$ var $16,3 \%$ (95\% KI 6,8-30,7\%) sensitiv og $97,3 \%$ (95\% KI 92,1-99,4\%) spesifikk for pasienter som fikk diagnosen alvorlig sepsis eller septisk sjokk i akuttmottaket. Sensitiviteten økte til 58,1\% (95\% KI $42,1-73,0 \%$ ) om man la til ett poeng for faktorene hjertefrekvens $>100$, sykehjemsbeboer, alder $>50$ år eller feber. I denne studien oppfylte altså omtrent åtte av ti pasienter som fikk diagnosen alvorlig sepsis eller septisk sjokk i akuttmottaket, ikke qSOFAkriteriene prehospitalt (7).

I en retrospektiv studie fra USA ble det over en tiårsperiode vist at alvorlig sepsis som innleggelsesdiagnose var vanligere enn både hjerteinfarkt og hjerneslag. Den samme studien viste at det $\mathrm{i}$ gjennomsnitt ble brukt $35 \pm 18$ minutt på hentestedet (8). Transporttiden kommer i tillegg. Det prehospitale tidsvinduet er altså stort, og representerer et viktig mulighetsrom for tidlig behandling av alvorlige infeksjoner. I store deler av Norge er det lang reisevei til sykehus. Nesten 60 kommuner har mer enn to timers reisevei til sykehus med akuttfunksjoner (9).

\section{En potensiell fare?}

Vår kliniske erfaring er at SIRS-kriteriene blir oppfylt før qSOFA-kriteriene. Denne erfaringen støttes av Seymour og medarbeideres studie omtalt i forrige avsnitt (8). Her fant man at hos sepsispasienter utenfor sykehus var hypotensjon et uvanlig funn, mens over halvparten av pasientene hadde takypné og takykardi.

Det er velkjent og innarbeidet både i primær- og spesialisthelsetjenesten at man ved sepsis skal starte antibiotikabehandling så raskt som mulig. Om hele behandlingskjeden nå i praksis setter likhetstegn mellom qSOFA-skår $\geq 2$ og sepsis, vil vi miste en gruppe alvorlig syke pasienter som tidligere raskt fikk livreddende behandling. Infeksjoner representerer et kontinuum fra harmløse forkjølelser til alvorlige infeksjoner med høy mortalitet. Sepsis definert etter qSOFAkriteriene er en av de mest alvorlige presentasjonsformene av infeksjonssykdommer. 
Ofte vil vi kunne identifisere alvorlige og behandlingstrengende infeksjoner før to eller flere qSOFA-kriterier er oppfylt, blant annet ved å bruke SIRS-kriteriene. Dette taler mot bruk av qSOFA-kriteriene alene.

\section{Faglige retningslinjer på villspor?} Norsk elektronisk legehåndbok (NEL) har fjernet SIRS-kriterier fra sepsiskapitlet og erstattet det med qSOFA-kriterier (10). Det samme gjelder Nasjonal faglig retningslinje for antibiotikabruk i primærhelsetjenesten (11). Her presiseres det at målet er å «Identifisere tilstanden. Innlegge pasienten øyeblikkelig. Ved lang transportvei, sette i gang behandling før transport». I retningslinjen beskriver man at qSOFA-skår kan predikere om pasienten har sepsis bedre enn de gamle SIRS- kriteriene. Videre står det at tilstedeværelse av de tre qSOFA-variablene innebærer sterk mistanke om sepsis. Mistanken styrkes ifølge retningslinjen ytterligere ved takykardi, avvikende kroppstemperatur eller høye eller lave hvite (SIRS-kriteriene) (11). Etter vår mening er dette eksempler på feil bruk av de nye sepsiskriteriene.

\section{Vår hovedbekymring}

Gapet mellom SIRS-kriterier og qSOFAkriterier gir oss et tomrom som inneholder pasienter med alvorlig infeksjon, der rask oppstart av behandling er avgjørende selv om qSOFA-kriteriene ikke er oppfylt.

Når inngangsporten til sepsisdiagnosen blir smalere, vil noen pasienter som tidligere fikk tidlig livreddende behandling nå ikke få det. SIRS-kriteriene er etter vår oppfatning fortsatt det beste instrumentet vi har for tidlig å sannsynliggjøre at pasienter har en alvorlig infeksjon og trenger rask oppstart av antibiotika.

Å flytte fokuset vekk fra SIRS-kriteriene som tegn på en dysregulert vertsrespons og livstruende sykdom, til andre kriterier som er relatert til økt risiko for død, vil trolig føre til redusert oppmerksomhet omkring tidlig behandling ved mistanke om sepsis. Vi tror at dette spesielt kan gjøre seg gjeldende utenfor sykehusene. I Nasjonale retningslinjer for antibiotikabehandling utenfor sykehus anbefaler man prehospital opp- start av antibiotika ved sepsis og lang transportvei (11). Endrede sepsiskriterier kan komme til å ramme pasientene i disse områdene hardt.

\section{Veien videre}

God akuttmedisinsk behandling krever helhetlige pasientforløp med samkjørte behandlingsalgoritmer mellom de ulike nivåene $i$ helsevesenet. Dersom man innfører de nye sepsiskriteriene uten først å sikre at dette ikke fører til en nedprioritering av pasienter med alvorlige infeksjoner, vil resultatet i verste fall kunne bli forsinket diagnostikk og behandling.

Vi mener at man i klinisk praksis fortsatt bør bruke SIRS-kriteriene som ledd i å diagnostisere alvorlige infeksjoner. Ved transporttid over 30 minutter bør pasienter som oppfattes å ha alvorlig infeksjon, vurdert blant annet etter SIRS-kriteriene, behandles med antibiotika. De nye sepsiskriteriene kan brukes for å identifisere sepsis og utløse raskest mulig transport inn til sykehus og sepsismottak ved ankomst. Nye prosedyrer for håndtering av sepsispasienter på legevakt, i ambulansetjeneste og akuttmottak bør baseres på nært samarbeid mellom kommunehelsetjenesten og spesialisthelsetjenesten.

\section{Steinar Konradsen}

steinar.konradsen@lenvik.kommune.no Aslak Hovda Lien

Steinar Konradsen (f. 1981) er spesialist i allmennmedisin. Han er assisterende kommuneoverlege i Senjalegen og medisinskfaglig ansvarlig lege ved Intermediæravdelingen, Distriktsmedisinsk senter Midt-Troms.

Forfatter har fylt ut ICMJE-skjemaet og oppgir ingen interessekonflikter.

Aslak Hovda Lien (f.1972) er spesialist i allmennmedisin. Han er kommuneoverlege i Senjalegen og medisinskfaglig ansvarlig lege ved Finnsnes interkommunale legevakt.

Forfatter har fylt ut ICMJE-skjemaet og oppgir ingen interessekonflikter.
Litteratur

1. Singer M, Deutschman CS, Seymour CW et al. The third international consensus definitions for sepsis and septic shock (sepsis-3). JAMA 2016; 315: $801-10$

2. Dellinger RP, Levy MM, Carlet JM et al. Surviving Sepsis Campaign: international guidelines for management of severe sepsis and septic shock 2008. Crit Care Med 2008; 36: 296-327.

3. Liu V, Escobar GJ, Greene JD et al. Hospital deaths in patients with sepsis from 2 independent cohorts. JAMA 2014; 312: $90-2$

4. Franchini S, Duca A. qSOFA should replace SIRS as the screening tool for sepsis. Crit Care 2016: 20: 409.

5. Vincent J-L, Martin GS, Levy MM. Authors' response. Crit Care 2016; 20: 409

6. Makam AN, Nguyen OK. Clinical criteria to identify patients with sepsis. JAMA 2016: 316: 453.

7. Dorsett M, Kroll M, Smith CS et al. qSOFA has poor sensitivity for prehospital identification of severe sepsis and septic shock. Prehosp Emerg Care 2017: 1 -9. E-publisert 25. januar 2017.

8. Seymour CW, Rea TD, Kahn JM et al. Severe sepsis in pre-hospital emergency care: analysis of incidence, care, and outcome. Am J Respir Crit Care Med 2012; 186: 1264-71.

9. Norges offentlige utredninger. Først og fremst et helhetlig system for håndtering av akutte sykdommer og skader utenfor sykehus. NOU 2015: 17.Oslo: Helse- og omsorgsdepartementet, 2015. https://regjeringen.no/no/dokumenter/ nou-2015-17/id2465765/sec1 (23.1.2017).

10. Norsk elektronisk legehåndbok. Sepsis. https://legehandboka.no/handboken/kliniskekapitler/infeksjoner/tilstander-og-sykdommer/ bakteriesykdommer/sepsis/ (23.1.2017).

11. Nasjonal faglig retningslinje for antibiotikabruk i primærhelsetjenesten. Sepsis. Helsedirektorate (oppdatert 3.11.2016). http://antibiotikaiallmennpraksis.no/index.php?action=showtopic $\&$ topic $=$ 45jQw4mZ\&j=1 (23.1.2017).

Mottatt 31.1. 2017, første revisjon innsendt 23.2. 2017, godkjent 27.3. 2017. Redaktør: Kaveh Rashidi.

Publisert først på nett. 